\title{
Anthropocentrism and Taxidermy in Santiago Nazarian's Neve negra
}

FERNANDO VARELA

Vanderbilt University

\begin{abstract}
In the present essay, I argue that taxidermy is a fundamental element in Brazilian novelist Santiago Nazarian's Neve negra (2017). To do so, I frame my argument by using studies on anthropocentrism and the relationship between the human and the non-human through taxidermy. The first part of the essay examines recent studies on taxidermy and primary sources from the nineteenth century that center on the art and science of skinning, preparing, and mounting dead specimens. The second part focuses on a close reading of Nazarian's novel by studying the narrator's patriarchal and masculine anxieties in conjunction with taxidermy and the non-human characters that appear in the novel.
\end{abstract}

Keywords: Embalmed animals, non-human, masculinity, patriarchy, snow

Gary Steiner has affirmed that "one can understand the sources of our own anthropocentric prejudices and use that history as the basis for a radical rethinking of the moral status of animals" (35). In order for this type of understanding to be properly implemented, he argues that we should depart from the Cartesian way of interpreting the value of individuals. Distancing himself from animal ethicists who use intellect as the only barometer for measuring the importance of animal species, Steiner proposes a kind of alternate belonging: "the doctrine of belonging (oikeiosis) could be reconceived so as to constitute a sphere of kinship among all beings that struggle for life and well-being, not simply among all beings that are rational and linguistic in the specifically human sense" (250). For Steiner, thinking about animals should also imply rethinking 
our modes of thinking itself. By demystifying this teleological way of seeing the natural world - ranking species based on how "smart" they are-we become aware of anthropocentrism's influence over our views on interspecies relations. It is precisely such a project of demystification that informs Santiago Nazarian's most recent novel, Neve negra (2017). The plot centers on the nightmares of an artist named Bruno Schwarz upon returning home to Brazil's coldest city on its coldest day. The protagonist, who is also the narrator, discusses the anxieties and doubts he faces as the father of his sexually ambiguous son, Álvaro (nicknamed "Alvinho" and "Vinho"), and his estranged and possibly unfaithful wife, Bianca. Among several frightening elements, one is particularly persistent in the novel: embalmed animals. From beginning to end, Bruno is struck by the sight of the figures he encounters throughout his nightmarish moments at home. I argue that taxidermy is a fundamental part of the novel as the protagonist faces his own anthropocentric and heteronormative prejudices and anxieties. To do so, I examine the use of taxidermy in the novel as a medium of human expression, and how the supernatural and non-human characters subvert such process. ${ }^{1}$

From the Greek words "taxi" and "derma," taxidermy literally means "organizing skin." The process is as follows: the dead specimen is flayed, its innards are thrown away, and its remaining skin is filled with a solid material in such a way as to resemble its formerly lived form. According to Melissa Milgrom, the first person to use the word taxidermy was Louis Dufresne, a taxidermist at the National Museum of Natural History in France (5). In 1803, the scientific reference book Nouveau dictionnaire d'historie naturelle (New dictionary of natural history) published an entry written by Dufresne titled, "Taxidermie." In it, he argues that "the natural sciences could not necessarily make progress until museums expanded and perfected the art of preparing, mounting, and conserving animals" (507). In describing the specific steps required to carry out the process, Dufresne dedicates one section to the proper way of hunting the specimens to be embalmed: "when the passion of hunting is combined with the happiness of knowing how to preserve the individuals one has procured, one must prefer a rifle with two barrels" (516). While the left barrel

\footnotetext{
${ }^{1}$ Taxidermy likely forms part of what Nazarian refers to as "existencialismo bizarro." According to the author, bizarre existentialism is the juxtaposition of classical works of literature and film with works of popular culture. In his own words, it would be something like placing William Shakespeare and zombies in the same sentence (Luciano Trigo, "De adolescentes e zumbis.")
} 
should contain small lead bullets for small birds, the right one should have bigger bullets to take down big animals. The passion for hunting is thus a byproduct of the desire to procure and end the life of what was just hunted. But the chase does not end with death. In fact, it is where life begins - one in which only deceptive surfaces, postures, stillness, and appearances matter.

In 1820, scientist Sarah Lee published a translation of Dufresne's article. In the preface, she describes taxidermy as a museum art form of tremendous aid to scientists unable to bring back living exotic species found in distant geographic regions. For her, the art and science of taxidermy "operated a favorable change in the classification and arrangement of the productions of nature" (2). In 1840, William Swainson wrote of the importance of having species be "still" while classifying and analyzing them. He affirmed that "in order to acquire a more accurate knowledge of their external form, and to investigate their internal structure, it is absolutely necessary to examine them in a dead state" (1). He describes taxidermy as "an art, therefore, absolutely essential to be known to every naturalist; since, without it, he cannot pursue his studies or preserve his own materials" (1). What both writers highlight is the need to immobilize that which needs to be studied, to crystallize what was once a living thing moving on its own. In doing so, the taxidermist is able to orchestrate a menagerie that seems - but is not - organic. It is an illusory enactment of life contained in a monitored premise, one that reflected the desire of more than a few Victorian scientists to control species beyond their reach.

Montagu Brown, who in 1844 authored one of the most popular books on taxidermy during the whole of the nineteenth century, certainly noticed its artistic layer. He underscores the impact appropriations of embalmed animals had for history. By exacerbating or otherwise distorting the anatomical features of animals into caricaturized gestures, such as macabre smiles or angry expressions, taxidermy effectively straddled the line between seriousness and comedy. According to Brown, inventive misuses of a strategy so valued by naturalists were not detrimental; rather, they helped pave the way for the history of taxidermy as both art and science in several social groups: "the modeling and the varied expressions of hope, fear, love, and rage, were an immense step in advance of the old wooden school of taxidermy; specimens, which are still to be found in museums - stiff, gaunt, erect, and angular" (12). For Brown, taxidermy had become an equally scientific and artistic endeavor to manipulate species. Indeed, 
the "expressions" that Brown mentions are highly subjective efforts to confine animals into a way of being that reflects above all the desires of the embalmer. Reconfiguring the skins of organisms so they show an array of emotional looks implies that taxidermy was not just used for scientific projects: it also helped humans to paralyze creatures, to petrify them into an immortal and determined pose that seemed alive, but was far from being so.

Taxidermy has recently become a preferred topic for more than a few scholars across several disciplines. Melissa Milgrom asserts that taxidermy was the window natural historians and hunters needed to understand nature, however subjective the process. She argues that taxidermy, or "to imitate nature with a fidelity that verges on the pathological" (2), was as close as naturalists could get to being in contact with untamed species. Following a similar path, Rachel Poliquin claims that the yearning to define the natural world - always elusive and ungraspable - is at the heart of taxidermy (6). Desire, amazement, order, and memory are all part and parcel of the process. To address this sense of longing, taxidermy serves as a simulation, an enclosed spectacle that reassures owners that wandering creatures have been captured, immobilized, and put on display.

Karen A. Rader and Victoria E. M. Cain state that museums have recently become more interested in exhibiting, rather than collecting, specimens. Most curators of natural history are no longer focused on truthfully mimicking ecosystems, but on arranging them in such a way as to appeal to visitors. As a result, dioramas become the center stage to attract spectators who already have a preconceived way of seeing other species (53). Giovanni Aloi has even more recently discussed how speculative philosophy can be used alongside taxidermy to address serious contemporary dilemmas. Examples Aloi utilizes include climate change, capitalism, mass extinction, and the Anthropocene. For him, embalmed dead animals are things with the capacity to unearth and rethink our relationship with animals alongside other pending issues: "The matter is not so much whether these objects vacillate between the ontological status of natural or man-made, but that they essentially are commodities that can enable the retrieval of discursive formations, cultural conditions, practices, and power/knowledge relationships between humans and animals" (53). Aloi implies that embalmed species, albeit no longer living, have the capacity to destabilize ontologically binary oppositions. Taxidermy, so the author implies, forces humans to excavate how they define and are defined by animals and plants captured and placed on 
exhibit. What interests Aloi is not distinguishing between the natural and the artificial, but to disrupt the whole contrast itself by emphasizing how nature and art cross-pollinate one another as they codify the other. By arranging organic skins into artistic poses, humans imprison organisms into a crystallized way of living in which art and life imitate each other.

What Milgrom, Poliquin, Aloi and others theorizing taxidermy have in common is their rendering of the practice as a manipulative device. It concretizes the human desire to apprehend, restructure, and exhibit an anthropocentric vision of other plants and animals. While helping scientists to analyze species up close without the risk of decomposition, it also sets the stage for an interplay of power structures beyond merely scientific endeavors. Species are no longer seen as kinetic beings moving autonomously. Instead, they are paralyzed into non-living things pretending to live. The skin remains, but everything else inside - the spark that makes life possible - is thrown out. Cotton, wire, and other chemicals are here human tools meant to counteract the process of decomposition. For a hunter, to lose or let a prey escape implies lacking evidence of the deed, but so is letting the trophy decompose into fragmented matter and return to the biosphere.

In his 1880 handbook on hunting, Rowland Ward points out that artistic techniques are essential to make a dead animal look alive: "in order to produce the life-like form of any animal by the employment of its preserved natural features, not only technical skill, but knowledge and artistic feeling are necessary to the production of a worthy work" (53). The desire for the hunter to reproduce life-like forms of what was hunted finds expression in William Adolph BaillieGrohman's memoir published in 1882. Both a hunter and a historian of hunting, Ballie-Grohman recalls in one passage the great antlers of a deer he once hunted. He writes, "I know of no trophy of days spent in the far-off wilds that will recall stirring memories in more lifelike and warmer colors, or fill your soul with such longing desire to return speedily to the well-known glade in the forest, where in a fair struggle the bearer of yonder head found in you his master" (121-22). He also speaks of the role the taxidermist has in determining the trophy's quality: "the skill of the taxidermist has not been uselessly expended upon this cherished souvenir of the Rockies, and the grand old fellow looks down with a very lifelike calmness of mien from the broad expanse of the tapestried wall reserved to him, where in stately exclusiveness he has found his last home" (122). Hunting and taxidermy create the trophy as proof of the hunter's success and superiority. The 
"fellow" is dead, but he nonetheless looks more alive than ever in the hunter's house. Its illusory animation is the stimulant for the killer to remember how there was once a self-moving entity, now immobilized and made into a commodity.

On a broader scale, the human yearning to apprehend life in an illusory state that risks as much as it promises recalls the blurry lines that Giorgio Agamben traces out between human and non-human animals. According to Agamben, it is time for humanity to reconsider its entitled position as superior to other animals. By tracing what has been thought on the human as an animal in relation to other species, he argues that there are significant effects that the human/animal dichotomy has created in various fields of study. Agamben affirms that there is a constant necessity to define the human vis-à-vis the non-human: "the relation between man and animal marks the boundary of an essential domain" (21). He identifies this domain as a site of interrogation pertinent to all studies: "It is as if determining the border between human and animal were not just one question among many discussed by philosophers and theologians, scientists and politicians, but rather a fundamental metaphysico-political operation in which alone something like 'man' can be decided upon and produced" (21). Agamben also points out that this vanishing line problematizes all sorts of conventional distinctions that have been keeping humans and non-humans away from each other: "When the difference vanishes and the two terms collapse upon each other - as seems to be happening today - the difference between being and the nothing, licit and illicit, divine and demonic also fades away, and in its place something appears for which we seem to lack even a name" (21).

Building on the motif of fading difference, Agamben speaks of the "anthropological machine." Here the human is an apparatus "suspended between a celestial and terrestrial nature, between animal and human - and, thus, his being always less and more than himself" (29). Nazarian may be said to make his reader imagine a taxidermic machine; at its center is a dead animal reconstructed by humans to appear alive and an artificial production made and inspired by organic parts. Suspended in complex and shifting webs of classification, taxidermy simultaneously resides in and disrupts anthropocentrism. It fluidly navigates between two antipodes, uniting them in a network filled with contradictions and baroque ways of interpreting human existence itself. Nazarian's Neve negra directly addresses the promises and pitfalls that taxidermy has made to the anthropological machine in an age of human control over the biosphere. 
Set in the small town of Trevo do Sul in the state of Santa Catarina, Neve negra's plot is especially concerned with the anthropocentric manipulation of skins. Commercially successful but frustrated artist and frequent traveler Bruno Schwarz returns home to his wife, their seven-year-old son, and their dog. It all begins when the narrator, tired from his travels, discovers that his Belgian Shepherd, Preta, has died under mysterious circumstances. Soon after, he sees that a stranger is standing in front of the house. This person is the grandson of the neighbor next door, Sr. Grüne, and he also claims to be Thomas Schimidt, the writer of $O$ coelhinho lindo, which is the children's book that Bruno reads to Alvinho prior to the encounter. ${ }^{2}$ Offering help to bury Preta out in the forest, this mysterious neighbor informs Bruno of a local legend focused on the Trevoso, who is said to come out on the coldest day of the year to haunt the first family he finds. His main trick is to kill off the oldest family member and occupy the body of the youngest one, disrupting in the process the entire family structure. As explained by Thomas, the Trevoso "mata o morador mais velho, ocupa o lugar do mais novo, perturba a ordem do lugar" (80). Afterwards, they dig a grave for Preta at a nearby forest and bury her under the snow, and Bruno is finally able to get some sleep.

It is from this moment, however, that strange things start to happen in the house in a manner similar to that of Stanley Kubrick's film The Shining (1980). After waking up a couple of hours later, Bruno discovers that the person sleeping next to him is not his wife, but actually his son, prompting him to jump out of the bed and chase him down the hall. Just as he is about to grab him, Alvinho falls down the stairs and appears to break his neck. Desperate, the narrator calls the police but soon discovers that there is nothing they can do, since the snow has covered all the roads. When Bruno turns around, however, his son's body is no longer there, and the boy begins to run around the house and toward Bruno's studio. Once there, Bruno discovers that Alvinho has ruined his paintings by making scratches and drawing animals. It is from this moment that Bruno

\footnotetext{
${ }^{2}$ Despite the fact that the young man claims to be the writer of the children's book (which appears in its entirety in the novel and includes a cover with the name "Thomas Schimidt"), there are several instances in which the narrator apparently does not make the connection and still believes not to know this character's name. Nonetheless, I refer to this character by the name "Thomas" for the sake of clarity. For more information on Thomas Schimidt and his presence in Nazarian's work, see Christopher Lewis's “When the Glass Slips: Jung, Transmodernism, and Santiago Nazarian's Thomas Schmidt."
} 
becomes infuriated with his son, grabs his rifle, and turns into what he calls "o Jack Torrance do Planalto Serrano" (110), a direct reference to Kubrick's film. Soon afterward, Bruno receives a call from Bianca, who tells him that both she and Alvinho have actually never been in the house, because they could not return due to the snowy conditions. The narrator then quickly deduces that the Trevoso has been the one playing tricks by pretending to be the youngest member of his family: his own son. Fearful and frustrated, Bruno decides to hunt down this supernatural creature once and for all, but his delusional state only results in more damage and complications: he accidentally perforates his stomach with a piece of glass, he kills both Thomas and his taxidermist grandfather, and finally, he shoots the real Alvinho when he and Bianca finally manage to return to the house. The novel then finishes with radio hosts, who describe the incident of a famous artist who "unintentionally" killed his son (confirmed to be so through a DNA study) in a house on the outskirts of Trevo do Sul.

As Bruno spirals down into a hallucinating condition that includes talking to the demonic-looking Trevoso and witnessing reanimated embalmed animals (some of which can speak), he also obsessively meditates on his role as a father who is masculine and proudly heterosexual. Indeed, it is of great concern to Bruno how to be a guide for his androgynous son, who does not comply with conventional gender norms. Having a son is good news for the main character, for it gives him a reason to brag to his colleagues, letting them know that he, as a straight man, has not fallen short of expectations: "agora, como pai orgulhoso, ou colega competitivo, posso tirar o celular e mostrar uma das fotos mais recentes de Alvinho" (22). Bruno hopes his son to be "moleque, guri, menino, masculino, destinado a seguir meus passos" (22).

Bruno notices that Alvinho is not like him at all, however. The boy is not drawn to what Bruno considers to be "masculine," nor does he demonstrate any interest in predatory animals. Instead, Alvinho is fascinated by rabbits, a fact that troubles Bruno: "Não entendo essa fascinação do meu filho por coelhos, nem sei se deveria incentivar. Eu passei pelo quê, dinossauros? Teve a fasse dos dinossauros, a fase dos tubarões; colecionava fascículos sobre a vida animais selvagens, comprados semanalmente na banca da praça" (26). It is specifically in this moment that the narrator expresses his boyhood interest in predatory animals: "por animais selvagens entenda-se predadores - e disso o que um menino gosta. Isso porque eu era uma criança bitolada, geralmente a grande 
paixão é o futebol. Não entendo um menino que gosta de coelhos" (26). The narrator feels distant from his son in that, unlike him, Alvinho is drawn to rabbits and not ferocious and violent animals. In choosing to use the word "predadores," Bruno sets the stage for perhaps his most defining quality as a father in crisis: the act of hunting and the expression of violence toward the non-human.

Concerned that Alvinho is not masculine enough and worried even more that the boy is not really his biological son, Bruno becomes driven by a need to kill the dangerous Trevoso. Patricide, infanticide, and hunting form the novel's three thematic supports, as a delirious father tries to come to terms with his son's androgynous behavior, his wife's supposed infidelity, and his own hallucinations.

A fourth element, however, is also fundamental to understand the narrative: the embalmed animals Bruno encounters throughout his story. Far from being a self-effacing product in the background, taxidermy becomes a major feature of the novel as the narrator faces his insecurities and demolishes his personal life. Bruno becomes the hunter of the story, killing the other characters in a desperate effort to maintain his patriarchal power.

In the fifth fragment of the novel, an embalmed rabbit and fox appear in Alvinho's room. Bruno imagines chastising his wife for procuring such bizarre decorations for their son, but he quickly begins to speculate about their source:

Olho para os animais empalhados. Não é algo de bom gosto nem como objeto de decoração nem como trabalho taxidérmico. Muito menos como brinquedo de criança. Deve ser obra de um taxidermista amador, a quem Bianca recorreu tentando consolar nosso filho. Que ideia de merda. Há o velho alemão, sr. Grüne, que vive na casa ao lado. Ele poderia passar por um avô. Tento me lembrar se Bianca ou Vinho já o chamaram de "vovô Grüne," pode ser. Nunca estive dentro da casa dele para dizer que não é um taxidermista. Nunca me sentei no colo dele para dizer que não é um avô. De repente, caçador e taxidermista. Mata raposas e coelhos da região e os empalha. Fica sabendo da perda do Vinho e o presenteia com um de seus trabalhos. $\mathrm{O}$ menino adora $\mathrm{o}$ presente e pede outro animalzinho. Assim temos um coelho e uma raposa empalhados no quarto do nosso filho. (43) 
Bruno is dumbfounded at the sight of embalmed animals in his son's bedroom. What follows, however, is a non sequitur: because there are "animais empalhados" in their son's room, the boy must be the result of an affair Bianca had with a taxidermist. What makes Bruno's argument even more slippery is that their elderly neighbor, Sr. Grüne, is a taxidermist, and Bruno imagines that he must have given Alvinho the embalmed rabbit and fox. Consequently, the narrator makes a direct connection between taxidermy and infidelity. Like the animais empalhados, Bianca appears to be something that she is not: a loyal wife. Bruno distrusts taxidermy just as he distrusts his own family members. The latter, like the embalmed rabbit and the fox, are organic as much as they are artificial. They pretend to love him, but then they take away his role as man of the house and give it to the aged taxidermist next door. It is in this way that Bruno will start placing layers of skin on his own interpretations of reality, and remodeling others according to what he believes. It does not matter what lies inside the others, nor what they actually think. What does matter is how the narrator chooses to mold their external contours and fashion a version of life with him at the top.

Bruno affirms his distaste for taxidermy, but he also does not fail to capture, eviscerate, and mount others in his own way. After throwing his son down the stairs for having slept in his bed without consent, Bruno enters into a kind of catand-mouse game where nothing should be taken at face-value. Examples include Alvinho running away when Bruno thinks he is dead, Bruno running into the Trevoso creature, and Bianca's vanishing presence. Despite these bizarre happenings, what Bruno wants most is to find his now-missing son and to murder whatever is lurking in the shadows of his home. He roams around the premises and plans to shoot anyone who crosses his path. The rifle is for Bruno both a weapon and an artifact that has been, like the house itself, the property of his father and grandfather: "Saio para os fundos, o quintal, o quintal, o ateliê, busco a velha espingarda. Está aí desde o tempo do meu pai, desde os tempos do meu avô. Há décadas não é usada. Lembro de tê-la visto funcionando, talvez quando criança" (69). The rifle is part of Bruno's patriarchal inheritance, and the narrator uses it to continue a tradition rooted in violence. Although initially not wanting to shoot, Bruno does indeed use the gun in the end, murdering his son under the supposition that he is shooting at the Trevoso. From the moment Bruno grabs the rifle and turns aggressive toward others, it is clear that blood will soon flow. 
Made into a hunter after experiencing a set of nightmares, Bruno does not turn a blind eye to taxidermy. Instead, he is more drawn to it. Recalling that the neighbors are definitely behind the kidnapping of his son and the missing rifle, Bruno goes to their house to find only a dead Sr. Grüne and his scared grandson. Furious and unresponsive to requests, Bruno eventually kills Thomas with a gun lying nearby, but not before taking notice of the embalmed animals that lie around him. As he enters the bedroom where the taxidermist lies dead, the decorations all of a sudden start moving and taking over the house: "Uma raposa salta de cima da estante, crava as garras no meu ombro e corre para longe. Os animais empalhados estão ganhando vida e eu estou perdendo a minha. É justo. O Trevoso veio fazer isso. Matar quem já deveria ter morrido. Dar nova vida a quem pode ter vida nova. Derramar meu sangue para ressuscitar os verdadeiros donos do bairro" (123). With the hunter dying from a recent wound, those mounted as decorations are once again moving freely. As the embalmed animals gain back their kinetic features and independence, the patriarchal figure gradually loses his energy and begins to decay. By describing the power of life as a transaction, the shifting power structures favor those previously oppressed. The bite Bruno receives from the fox is also a reaction against the human use of animal skins. By sinking its sharp teeth into the hunter's arm, the embalmed creature retaliates against the oppressor, making the readers aware that animals do bite back and break through human skin.

As an archive of life and artificiality, taxidermy's interdisciplinary platform is also a topic of discussion in Neve negra. There is, for example, a dialogue between Sr. Grüne and the narrator in which they debate whether embalming animals is an art or a science. Nineteenth-century taxidermy blurred the boundaries between artistic and scientific ways of interpreting the natural world - and Bruno is aware of this fact. The narrator consequently pressures $\mathrm{Sr}$. Grüne to explain why taxidermy should be considered a science and not an art, given the fact that the taxidermist could certainly be considered a sculptor of sorts. Describing the process as a morphological study, the dead taxidermist explains: "Um estudo morfológico. Uma forma de preservar a morfologia, a aparência, as dimensões de um animal específico depois de morto. A única! Imagine um animal extinto! Que outra forma ele teria de continuar ocupando um espaço físico no mundo se não fosse pela taxidermia?"(126). An archive of natural history, taxidermy is for Sr. Grüne the mechanism by which we freeze 
biology so that we are granted a glimpse into the past. Taxidermy may have a tremendous impact for science to study the life of what no longer walks on this earth, but it is also the result of longing for what is no longer with us. As Poliquin explains, embalming animals brings to light a sense of human melancholy for those species that either we never had a chance to see or that we ourselves have obliterated from the earth:

Taxidermy is deeply marked by human longing. All organic matter follows a trajectory from life to death, decomposition and ultimate material disappearance. The fact that we are born and inevitably disappear defines us, organically speaking. Taxidermy exists because of life's inevitable struggle toward dissolution. Taxidermy wants to stop time. To keep life. (6)

If longing is to be interpreted as the driving force science uses to recreate a certain vision of life, then one also cannot exclude art. As Theodor Adorno argues, art is in dialectical relation with empirical reality: "Art's double character as both autonomous and fait social is incessantly reproduced on the level of its autonomy. It is by virtue of this relation to the empirical that artworks recuperate, neutralized, what was once literally and directly experienced in life and what was expulsed by spirit" (5). As an artwork in direct relation with empirical science, embalmed species manifest the human desire to stop the biological clock from effacing life itself. The great irony in sr. Grüne is that, despite his assertion that taxidermy is all about representing reality as it is, he cannot help but put a smile on his embalmed cat. Responding to Bruno's question whether or not art is the inability to faithfully reproduce an individual, the taxidermist responds: "Se o gato morreu sorrindo, o gato estará sorrindo" (127). It is precisely this kind of contradictory remark that defines taxidermy in the novel: the need to capture the other in a pose that best resembles the taxidermist's vision on the order of things. It is this imposition of smiling that a nearby embalmed cat will address with the narrator. The animal-human collision in the novel does not end with a wounded hunter and a dead taxidermist lying in bed. Bruno's dialogue with this cat speaks to the artistic and scientific implications of taxidermy. After the narrator kills $\mathrm{Sr}$. Grüne's grandson, he hears the cat speaking to him about the way he was embalmed. As a way to combat the assumption that taxidermy replicates animals 
as they once were, Nazarian provides the cat with a voice, and one that is not timid about expressing the animal's discontent: "É tu quem pode me dar sentimentos, dizer se estou chorando, se estou sorrindo. Um taxidermista não tem como compreender o que eu sinto" (132). Furthermore, the cat complains about the separation of taxidermy from art, given that only the latter can truly provide the elixir of life: "Eu te digo, o sr. Grüne não é capaz de me dar sentimentos, não é capaz de me dar vida" (133). Sr. Grüne may have given the cat a smile, but this is not enough if he is not committed to using art to maintain a version of life, and one that promises as much as it risks.

It is perhaps the Trevoso that best shows the repercussions of believing a misleading surface that covers what is underneath. The last couple of pages reveal the origins of a local legend: one about a son who was kicked out of the house for being gay. Alone and homeless, he eventually commits suicide by drowning in the ocean, but later he returns as a ghost seeking revenge. Bruno is not softened by this story, and he still intends to kill the strange-looking creature to remind himself that he, as the man of the house, will not succumb to the demands of a homosexual and supernatural being. What happens right after the Trevoso is about to leave ends in tragedy: all of a sudden Alvinho appears by the couch and Bruno shoots him, believing him to be the Trevoso playing tricks. Soon after, the reader realizes that all of the novel's events may have been the product of the narrator's imagination. Even the conclusion he reaches about Alvinho actually being the neighbor's son is false, since the last fragment of the novel tells us that DNA results confirm that the boy was indeed Bruno's son. The hunter has in the end become the hunted due to his own prejudices and patriarchal desires. Bruno started his own tragedy when he pushed his son down the stairs, implying that Alvinho was developing a sexual attraction towards his own father. The embalmed animals that appear throughout the narrative are manifestations of a father-son relationship built on lies, illusions, and the fear of having an androgynous son. Like a taxidermist, the father longed for his son to adopt a certain pose and maintain a particular form.

The Trevoso is the supernatural character who disrupts the narrative as well as Bruno's command over himself and his home. He is a non-human and spiritual entity who introduces the animal and the speculative layer in the novel, mixing both and confounding the main character's view of reality. Likewise, the Trevoso is the non-human and savage spirit who undermines the narrator's 
anthropocentrism by bringing wildlife and queerness into the house. As Thomas explains, the Trevoso is an "espírito selvagem que sai da floresta na noite mais fria do ano para buscar abrigo e aprontar as travessuras" (80). The name "Trevoso" is also reminiscent of darkness, terror, gloominess, and obscurity. He is that non-human, queer creature who disrupts the seemingly traditional and familiar setting. It is then only predictable that the Trevoso mesh with the androgynous-looking Alvinho to destabilize Bruno's concept of the family from the inside out. Bruno himself acknowledges that his own vision of the Trevoso projected onto his son is one mixed with animality: "Não é meu filho, é algo entre ele e o vizinho, idade intermediária, entidade animalesca, um espírito selvagem" (169). The fact that the narrator also associates his son to his neighbor (especially given that Bruno suspects him to be Alvinho's biological father) recalls Machado de Assis's Bento, who suspects Ezequiel to be Escobar's son.

While the Trevoso may be said to embody certain behavioral patterns akin to taxidermy-since his main power resides in camouflage - the novel also suggests that the taxidermist is Bruno himself. Towards the end of the storyline, the Trevoso tells the narrator that he, as an imaginary creature, is actually a blank space: "Como um bixo do mator, ele me examina sem compreender. Talvez só ofereça espaços em branco, como diz" (172). This statement hints at the possibility that the male narrator is the one human character imposing his own prejudices and misconceptions onto the wild spirit. This line of thought becomes more suggestive when the Trevosso reveals his master technique: reverse taxidermy, by inserting what appear to be Bruno's innards into a plush rabbit meant for Alvinho. Instead of continuing the traditional paradigm in which the hunter captures and skins the prey, the Trevoso uses the hunter's insides to reverse the process. According to Bruno, "nas mãos dele, o coelho fofo de pelúcia destinado a Alvinho, murcho. Barriga aberta, ele recheia com uma matéria orgânica vermelha e me pergunto se são minhas próprias tripas" (170). The Trevoso himself then affirms: "rechear o bicho da pelúcia com vísceras reais. Vou chamar de taxidermia reversa" (170). The supernatural non-human subverts the anthropocentric paradigm of taxidermy by stuffing human innards in a human-made plush. The human hunter ceases to be the predator in order to become trapped in his own taxidermic project.

This entire storyline, in which the hunter becomes hunted by his own anxieties, takes place in a setting in which snow predominates. Although initially 
suggested to Nazarian by his press, snow still plays an important role in the novel, one that goes beyond a nod to Kubrick's The Shining. As a natural element that freezes life in a manner similar to that of taxidermy, snow further adds a layer of anomaly and mysteriousness in the specific case of Santa Catarina, where tourists go precisely because snow is such an odd phenomenon in Brazil. Yet, the radio hosts who appear in the first pages of the novel - and to whom Bruno listens as he drives to his house - say that in Brazil snow is much harsher than in Europe because the former does have houses insulated against such weather. Snow appears on almost every page of the novel, as the narrator enters into the cold and ominous world dominated by the Trevoso. Since this creature is synonymous with darkness and obscurity, it becomes possible to visualize black snow spreading through Bruno's mind as he tries to defend his family, especially his son. For example, when he finds what appears to be Alvinho pointing out the window, the narrator states: "os sonhos infantis colocando os perigos no mundo externo, além do quarto, na neve negra, o frio desconhecido" (32). This black snow that freezes life as it creates a gloomy and cold environment later takes the shape of the Trevoso himself, which reverses taxidermy in front of main character. As he states, "se o Trevoso sai para brincar na noite mais fria do ano, hoje deve estar eufórico" (120). The importance of snow then resides precisely in being not only an oddity in the country in which the story takes place, but also in that it is closely associated with queerness and the supernatural.

While Neve negra focuses on taxidermy, it is not Nazarian's only novel to focus on animal-human relations. In Mastigando humanos (2013), for instance, he focuses on the existential crisis an alligator faces as he moves from the swamps to a city, lives in the urban sewer with his companions, and devours his human victims. What is peculiar about this alligator is that he is also the narrator and faces a series of events, including an Orwellian dictatorship led by rats, life in college, and what it is like to talk about humans literally under their feet. Another of Nazarian's books that addresses our obscure connections with other forms of life is Biofobia (2014). In this novel, a rock singer returns to his home in the countryside after his mother has committed suicide. What should have been an uneventful couple of days turn into nightmarish scenes when the main character senses that the surrounding landscape is turning against him. Both novels exemplify Nazarian's interest in deciphering human relations with other species in a world where humanity is the author of its own destruction. 
Nazarian's work is central to Brazilian speculative fiction, a genre that also includes science fiction. In his study of science fiction, horror, and fantasy in Brazil, Roberto de Sousa Causo defines speculative fiction as a genre that seeks to unravel a set of fictional possibilities: "Minha perspectiva é a da ficção especulativa como uma tradição diferenciada, que bebe de fontes míticas, satíricas, utópicas, romanescas, e mesmo científicas, para realizar-se como um corpo multifacetado de possibilidades ficcionais" (45). Of all these sources, however, Causo is specifically interested in myths and their function within speculative fiction: "aos usos, pela ficção especulativa, do poder do mito, tanto na obtenção de seus efeitos técnicos na narrativa, quanto na afirmação do seu modo peculiar de representação da realidade" (36). In the specific case of Neve negra, Bruno uses the myth of the Trevoso to create other fictional possibilities. By introducing the trickster into his novel, Nazarian employs mythology as a conduit to exploit the speculative powers of fiction. In doing so, he also addresses what Causo considers to be important for science fiction: the universe as a dynamic process in which several factors operate in order to relativize established visions (49). In the specific case of Brazil, as M. Elizabeth Ginway explains, science fiction "often projects Brazilian myths of identity from the past onto a society of the future" (16). Two of such myths are that of the patriarch and natural wonders, present from colonization to a twentieth-first century speculative work such as Neve negra. As a result, Ginway states that Brazilian science fiction is "an ongoing social narrative or political dialogue within Brazilian culture" (31). In the case of Neve negra, Nazarian uses taxidermy as an arsenal within his speculative narrative to study the patriarch and the Brazilian natural landscape in which he lives.

In Nazarian's novel, there is a traditional portrayal of taxidermy as an activity that showcases human domination. Bruno becomes a hunter of the non-human other as he tries to uphold the image of a heteronormative and traditional family. His attempt to shape his view of a family is directly tied to giving more precedence to appearance, which is a taxidermist's key goal: "enganamos, representamos bem, porque é isso o que somos. Ao menos, é isso o que se pode considerar uma família feliz, bonita, tradicional" (21). However, as the narrative progresses, taxidermy slips through the hunter's fingers as the Trevoso covers himself under Alvinho's "skin," while embalmed animals acquire a life of their own. Non-human beings undermine anthropocentrism through very same 
technique meant to freeze them into a lifeless form. On a broader scale, Nazarian's novel points to a productive correspondence between literature and taxidermy as two forms of expression that center on mimesis and the representation of life. It is certainly valid to make the claim that taxidermy and literature unavoidably portray the non-human within anthropocentric terms (given that both are forms of human-based creations). But I believe that Neve negra reveals another alternative, by which the non-human is able to subvert and turn on its head the very same medium that was meant to suppress it. Nazarian's interweaving of literature and taxidermy invites further discussions. Specifically, it encourages one to think of how both may mediate our growing desire to address the longings, anxieties, and pressing interrogations lying at the chasm between the human and other lifeforms.

\section{Works Cited}

Agamben, Giorgio. The Open: Man and Animal. Translated by Kevin Attell, Stanford UP, 2004.

Adorno, Theodor. Aesthetic Theory. Translated by Gretel Adorno and Rolf Tiedemann, Continuum, 1997.

Aloi, Giovanni. Speculative Taxidermy: Natural History, Animal Surfaces, and Art in the Anthropocene. Columbia UP, 2018.

Baillie-Grohman, Adolph. Sportsman's Handbook to Practical Collecting, Preserving, and Artistic Setting-Up of Trophies and Specimens to Which is Added a Synoptical Guide to the Hunting Grounds of the World. Simpkin, Marshall, \& Co., 1880.

Brown, Montagu. Practical Taxidermy: A Manual of Instruction to the Amateur in Collecting, Preserving, and Setting up Natural History Specimens of all Kinds, to Which is Added a Chapter upon the Pictorial Arrangement of Museums. L. Upcott Gill, 1884.

Causo, Roberto de Sousa. Ficção científica, fantasia e horror no Brasil, 1875 a 1950. U Federal de Minas Gerais, 2003.

Dufresne, Louis. "Taxidermie." Nouveau dictionnaire d'historie naturelle, appliquée aux arts, principalement à l'agriculture et à l'economie rurale et domestique, vol. 21, Cher Deterville, 1803, pp. 507-63.

Ginway, M. Elizabeth. Brazilian Science Fiction: Cultural Myths and 
Nationhood in the Land of the Future. Bucknell UP, 2004.

Lee, Sarah. Taxidermy or, the Art of Collecting, Preparing, and Mounting Objects of Natural History. Longman, Hurst, Rees, Orme, and Brown, 1820. Lewis, Christopher. "When the Glass Slips: Jung, Transmodernism, and Santiago Nazarian's Thomas Schmidt." Luso-Brazilian Review, vol. 52, no. 2, pp. 116-35.

Milgrom, Melissa. Still Life: Adventures in Taxidermy. Houghton Mifflin Harcourt, 2010.

Nazarian, Santiago. Biofobia. Record, 2014.

-. Mastigando humanos. Record, 2013

- Neve negra. Companhia das Letras, 2017.

Poliquin, Rachel. The Breathless Zoo: Taxidermy and the Culture of Longing. Pennsylvania State UP, 2012.

Rader, Karen A., and Victoria E. M. Cain. Life on Display: Revolutionizing U.S. Museums of Science and Natural History in the Twentieth Century. U of Chicago P, 2014.

Steiner, Gary. Anthropocentrism and its Discontents: The Moral Status of Animals in the History of Western Philosophy. U of Pittsburgh P, 2005.

Swainson, William. Taxidermy, Bibliography, and Biography. Longman, Hurst, Rees, Orme, and Brown, 1840.

Trigo, Luciano. "De adolescentes e zumbis." Máquina de escrever, Globo.com, 8 Sept. 2009, globo.com/platb/maquinadeescrever/2009/08/09/um-romancesobre-adolescentes-e-zumbis/.

Ward, Rowland. Sportsman's Handbook to Practical Collecting, Preserving, and Artistic Setting-Up of Trophies and Specimens to Which is Added a Synoptical Guide to the Hunting Grounds of the World. Simpkin, Marshall, \& Co., 1880. 